Khazanah: Jurnal Studi Islam dan Humaniora

ISSN: 0215-837X (p); 2460-7606 (e), Vol. 17 (1), 2019, pp. 25-52

DOI: $10.18592 /$ khazanah.v17i1.3022

Submit : 24/06/2019 Review : 27/06/2019 Publish : 30/07/2019

\title{
EXTINGUISHING FIRE, IGNITING TOLERANCE: FIRE FIGHTER COMMUNITY, CIVIL CULTURE AND TOLERANCE
}

\author{
Muhammad Sandi Rosyadi \\ Center for Religious and Cross-Cultural Studies, Gadjah Mada University \\ Muhammad.sandi.r@mail.ugm.ac.id
}

\begin{abstract}
The correlation between civil society and democracy is a big discussion in academic world. Democracy that engenders a civic culture is usually linked into a tolerant behavior in society. This study aims to understand how the participation of individuals in civil society, in this case is BPK (fire fighter community) in Banjarmasin, cause them to become more tolerance in a pluralistic society. In addition, this study also examines whether the involvement of member to BPK in Banjarmasin make them as an individual who is more attentive and tolerant towards different groups or vice versa.This study argues that there is a correlation between a personal membership in civil society with their augmentation in tolerance attitude. The case of fire fighter community in Banjarmasin shows an establishment of a brotherhood among its members. The attitude of "sanak ikam" or "your brother" brings up the attitude of civic members' tolerance of all the differences that exist in other individuals in general and differences in members of BPK in particular. Furthermore, on personal level, a member's attitude towards tolerance can also be affected by the diversity of members in BPK which they are affiliated with. However, BPK has the possibility of being a place for political contestation. On one side BPK has been playing a role in fostering tolerance in Banjarmasin society, on the other hand, it is possible in the future become a double-edged knife that even destroys the tolerance that has been formed.
\end{abstract}

Keywords: Civil Society; Civic Culture; Democracy; Tolerance

\section{Introduction}

There are debates among many scholars on the relationship between civil society and democracy. Some scholars such as Robert Putnam, Francis Fukuyama, and Neera Chandhooke argue that civil society is part of the success of democracy. According to Putnam, the civic association creates common values and connects community members to one to another and creates the system of the social order 
required for democracy. ${ }^{1}$ Then, Fukuyama argues that only by coming together in a civil association, a weak individual will become stronger. ${ }^{2}$ For Chandhooke, civil society has historically been connected with democratic values of participation, accountability and the construction of public discourse through life association which makes civil society so indispensable. ${ }^{3}$

On the other side, there are scholars who disagreed with the opinion of the civil society as part of the success of democracy. Instead, they believed that civil society has a role to undermine the democratic State. Joel Migdal believed that the lack of a state can be indicated by the number of community groups that have control over the public directly, and build their own system. ${ }^{4}$ This opinion was also supported by Sheri Berman, in accordance with Berman, in the case of Germany in the early of twentieth century shows the weakness of the state's role in addressing the growing civil society at the time. Berman used a term to describe it: "civil society was highly developed but segmented". The failure of the state in controlling these civil associations was used by the Nazi to establish a new political system and oppose the government. ${ }^{5}$ Thomas Corothers and William Barndt also showed the critical side of civil society. They believed civil society is very much concerned with private

${ }^{1}$ Robert D. Putnam, Robert Leonardi, and Raffaella Y. Nanetti, Making Democracy Work: Civic Traditions in Modern Italy (Princeton University Press, 1994), 16775.

${ }^{2} \mathrm{Mr}$ Francis Fukuyama, Social Capital and Civil Society (International Monetary Fund, 2000), 7.

${ }^{3}$ Neera Chandhoke, "Civil Society," Development in Practice 17, no.4 (November, 2018): 609 .

${ }^{4}$ Joel S. Migdal, State and Society: Studying How States and Societies Transform and Constitute One Another (Cambridge, UK: Cambridge University Press, 2003), 8-9.

5Sheri Berman, "Civil Society and the Collapse of the Weimar Republic," World Politics 49, no. 3 (1997): 426. 
economic interest. According to them, civil society is preoccupied with the pursuit of private and frequently parochial and grubby ends. ${ }^{6}$

One of the parts of society that plays an important role in democracy is the role of civil society. Michael Edward describes a civil society in three forms: a public sphere, an ideal form of society, and organization, ${ }^{7}$ in which engaged with public matters. As an essential element of democracy, civic society is a place for people to engage in public affairs. Within the context of a plural society like Indonesia, civil society may become a place to engage people who have different religious and cultural background and to prevent escalated violence or conflict. ${ }^{8}$

Interestingly, one form of civil society can be seen in the firefighter community in Banjarmasin as Barisan Pemadam Kebakaran (BPK). BPK was started by the initiative a group of people to assist the government in addressing and overcoming the fire disaster in Banjarmasin. In 1966, the first Barisan Pemadam Kebakaran (BPK) was established under the name of BPK HIPPINDO and continues to exist until the present time. ${ }^{9} \mathrm{BPK}$ in Banjarmasin has some characteristics of civil society as described by Larry Diamond, namely: first, as a group that is related to the public than private ends; second, as a group that helps the state or government;

'Thomas Carothers and William Barndt, "Civil Society," Foreign Policy 10, no. 3 (October, 1999): 23. DOI: 10.2307/1149558

${ }^{7}$ Michael Edwards, Civil Society, (Malden, USA: Polity Press, 2009), 76.

${ }^{8} \mathrm{~V}$. A. Gutorov, "Civil Society and the Theory of Democracy: a View from Intellectual Heritage of the XX-th Century," RUDN Journal of Political Science, no. 1 (December 15, 2015): 54.

${ }^{9}$ Achmad Sugianto, "Efektifitas Peran Serta Masyarakat Dalam Pengelolaan Pemadam Kebakaran (BPK) Mandiri Sebagai Fungsi Pelayanan Publik (Objek Studi : Kota Banjarmasin )" (Masters, Program Pasca Sarjana Universitas Diponegoro, 2001), 5, http:/ /eprints.undip.ac.id/11895/.

Khazanah, Vol. 17 (1), 2019 
third, as a group that has the ability to create spaces for pluralism and diversity. ${ }^{10}$

BPK itself is an open organization for individuals regardless of their background. According to BPS Banjarmasin 2015, Banjarmasin consists of various ethnic-Banjar, Dayak, Java, Madura, and Chinese, and religion-Islam, Catholicism, Protestantism, Hindu, Buddhism, and Local religions. ${ }^{11}$ Yet, there is no different requirement to become a member of BPK. Although some BPK has a religious background such as BPK Masjid Noor or BPK Seberang Masjid, they avoid discriminating to help other people. In fact, most of the members of BPK HIPPINDO who were the pioneer of BPK in Banjarmasin are Chinese, a minority ethnic in Banjarmasin. Thus, it is interesting to observe and examine the roles and contribution of BPK as a civil society toward tolerance in Banjarmasin and how the involvement of individuals in BPK has an impact on the tolerance between groups.

The discussion on the role of civil society in the success of democracy is a large-scale discussion which can assist to understand whether civil society can make an individual become more democratic or not. In this case, it is necessary to understand how the position of BPK members in Banjarmasin. As individuals who are directly involved with the civil society, the discussion helps to understand whether the members of BPK become more democratic, or vice versa.

"Cooperation" and "public awareness" are important keywords to explain civic characteristics. Cooperation does not only mean a collection

${ }^{10}$ Larry Diamond, "Civil Society and the Development of Democracy," Estudios/Working Papers (Centro de Estudios Avanzados En Ciencias Sociales), no. 101 (1997): 6.

${ }^{11}$ BPS Kota Banjarmasin, Kota Banjarmasin dalam Angka 2016 (Banjarmasin: Badan Pusat Statistik Kota Banjarmasin, 2016), 181. 
of individuals who work together but also have a voluntary characteristic and its role in raising public awareness about public issues. ${ }^{12}$ Moreover, cooperation should also have "trustworthiness." ${ }^{13}$ While, public awareness in this context discusses social problems, public policy, government action and matters of community and cultural identity. ${ }^{14}$ Therefore, the civic person cannot be separated from another analogy as a tolerant person. Tolerance is "putting up with something you do not like"15 and this means not only appreciating something different but also receiving to something we dislike or principle which against ours. ${ }^{16}$

Keywords that used to understand the concept of tolerance in this study are "accepting" and "difference". D.A.Carson explains two models of tolerance: first, a model which defines tolerance as accepting the existence of something different from them; accepts the presence of the others without having to believe the truth of the others. ${ }^{17}$ In contrast, the second model convinces not only accepting the existence of others but also receiving the essence of others. According to this model, tolerance means not only received different views but also believes that they have truth. ${ }^{18}$

${ }^{12}$ Mohammad Iqbal Ahnaf and Hary Widyantoro, "Democracy, Uncivil Society and Development: Evidence from Indonesian Province of Yogyakarta," Development Research Conference in Stockholm University Panel on Democracy and Development, 2016, 4.

${ }_{13}$ Putnam, Leonardi, and Nanetti, Making Democracy Work: Civic Traditions in Modern Italy (New Jersey: Princeton University Press, 1994), 197.

${ }^{14}$ Edwards, Civil Society (Malden, USA: Polity Press, 2009), 55.

${ }^{15} \mathrm{~W}$. Paul Vogt, Tolerance and Education: Learning to Live With Diversity and Difference, (Thousand Oaks, CA, US: Sage Publications, Inc, 1997), 1.

${ }^{16}$ Marjoka van Doorn, "The Nature of Tolerance and the Social Circumstances in which It Emerges," Current Sociology 62, no. 6 (October 1, 2014): 2, https://doi.org/10.1177/0011392114537281.

${ }^{17}$ Donald A. Carson, The Intolerance of Tolerance (Michigan: Wm. B. Eerdmans Publishing Co., 2012), 3.

${ }^{18}$ Carson, The Intolerance of Tolerance, 11.

Kharanah, Vol. 17 (1), 2019 


\section{Method}

This research is based on fieldwork in six BPKs in Banjarmasin. Data collection was done by using an observation and in-depth interview methods towards one people from each BPK in order to learn their views and perceptions about social problems and issues of tolerance. The interviews help to identify whether their involvement in civil society makes them more civic or tolerant. The six BPKs are categorized into two parts: first, three BPKs that have members from various backgrounds of religion and race. The second group is three BPKs in which the members have only one common background of whether religion, race or others.

Thera are some considerations for categorizing the six BPKs. The first three BPK have members from various backgrounds, whether religions, races, and the second three BPKs are those members of the BPK who have only one thing in the common background even religion, race and others. It refers to a form of social capital described by Robert Putnam that quoted by Muhammad Iqbal Ahnaf as bridging and bounding. Bridging is a social capital that is able to build inter-group connection, while Bounding is the social capital that is only able to build an in-group connection. ${ }^{19}$

Six BPKs organizations are chosen in this article by considering the homogeneity or heterogeneity of the members, and the establishment area. First, BPK Perintis which is a "family based" was established in 1999 by H. Faisal. Its member is around 90 people and most of them are from Banjar and Muslims. There are only two members who are not Banjarese (Javanese and Maduranese). The main office of BPK Perintis is located on Jalan Perintis Andalas, Pasar Lama, Banjarmasin, where many

${ }^{19}$ Ahnaf and Widyantoro, "Democracy, Uncivil Society and Development: Evidence from Indonesian Province of Yogyakarta," 6. 
important public places such as Police Main Office of South Borneo, military post, a mosque, and two churches. The religious institutions frequently ask BPK Perintis to help them organize religiousevents.

Second, BPK Masjid Noor, established in 1991 and affiliated to the Masjid Noor, is one of the biggest and oldest mosques in Banjarmasin. It has 58 members, who are Muslim in term of religion and in term of ethnicity 55 people of them are Banjar, two are Javanese and one is Bugisnese. BPK Masjid Noor is located right on the heart of trading activity and one of the populous area in Banjarmasin. Interestingly, most of the regular donator of Masjid Noor comes from the Chinese descendant merchants in the market around it.

Third, BPK Banua Anyar, established in 2006 by Haji Ahmad, it consists of 30 members, who are family relatives. Banua Anyar is a kampong based community, located near the Martapura River and has strong Islamic culture. The BPK is actively involved in many the kampong events such as Maulid, Hadrah competition, and Muharram Festival. In other words, its members are the main generator of kampong activity.

Fourth, BPK Seberang Masjid, established in 1987, is one of the pioneers of the firefighter community in Banjarmasin. It has 87 members from diverse ethnicity; 55\% Banjar, 25\% Javanese, 10\% Madurese, 5\% Chinese, and $5 \%$ Minang. This BPK is based on Jl. Kampung Melayu, one of the areas in Banjarmasin that have multicultural nuance. BPK Seberang Masjid has a strong influence among the BPK community in Banjarmasin. It is also actively involved in society. Even though most of the members involved with Masjid Ar-Rahman but they also help the HKBP churches to manage the parking lot and the traffic flow every Sunday.

Fifth, BPK Kompas was established in 1997. It is one of the biggest firefighter communities in Banjarmasin. It has 140 members divided into Khazanah, Vol. 17 (1), 2019 
two land platoon and one water platoon. Moreover, its members have a diversity of ethnicity and religion; 30\% Banjar, 27\% Chinese, 21\% Javanese, 15\% Maduranese, and the rest come from Bugis and Bataknese; 60\% Muslim, 25\% Christianity, 10\% Confucianism, and 5\% Buddhism. BPK Kompas main office is located on Jalan Veteran Banjarmasin which most of the resident is Chinese descendant. BPK Kompas also actively involved in the event held by the people around it regardless of their religious or cultural background.

Sixth, BPK Siring Tandean, was established in 2013 and has 25 members which most of them are Maduranese (40\%), Banjar (25\%), Chinese (20\%), Javanese (10\%), and Balinese (5\%). They also a diverse religious belief which predominantly Muslim (65\%), Christianity (20\%), Buddhism (10\%), Confucianism (2,5\%), and Hinduism (2,5\%). It is located on Jalan Pierre Tandean, at the center of Banjarmasin. Besides its emergency task every month, it helps to manage the traffic when there is a ritual in Klenteng Soetji Nurani. Moreover, a lot of members of BPK Siring Tandean are involved as Barongsai players during Imlek and Cap Go Meh festival.

\section{Discussion}

\section{Examining Civil Society}

According to Michael Edward, civil society can be classified into three forms. First, civil society as a public sphere, "the arena for the public even in the association or collaboration outside the parliament to debate or discuss matters relating to public affairs such as social problems, public policy, government action, community and cultural identity." ${ }^{20}$ Wolfe as cited by Lipschutz added that To talk civil society is to reserve the

${ }^{20}$ Edwards, Civil Society, 55. 
priorities of political economy and to confirm that human beings and their desires may alter other determinant stuctures. ${ }^{21}$ Second, civil society as, "a form of an advanced society that had a high civilization. If it was depicted as religion description, it's like ummab or Madani community in Islam $^{22}$ or Tikkeun Olam in Jewish. ${ }^{23}$ Third, civil society as an association. It is described as, "all associations and networks between the family and the state in which membership and activities are voluntary performed." ${ }^{24}$ The third form, "civil society as an association" is used to explain the term of civil society in this study.

Civic culture can also be referred to a civic virtue as an attitude of tolerance towards others, not only in their views but also in the role of others in the community. So that they collectively participate, and becoming a good member as part of society in order to solve problems that exist in that society. To create civic culture, people need to engage with others and participate in the public matters. Within this definition, civic engagement is the way of an individual to give a contribution to society. In other words, civic engagement is a significant element for the civil society. It is impossible to establish a civil society without civicengagement.

The discussion of the relationship between civic culture and democracy cannot be separated from the discussion between civil society and democracy. This discourse is still debated among scholars. The

${ }^{21}$ Ronnie D. Lipschuts, "Reconstructic World Politics: The Emergence of Global Civil Society," Millenium: Journal of International Studies 21, No.3 (December 1, 1992): 389, https://doi.org/10.1177\%2F03058298920210031001.

${ }^{22}$ M Zainal Abidin, "Civil Society dalam Wajah Keislaman dan Keindonesiaan," Khazanah: Jurnal Studi Islam dan Humaniora 12, No. 2 (August 8, 2014), https://doi.org/10.18592/khazanah.v12i2.1607.

${ }^{23}$ Edwards, Civil Society, 38.

${ }^{24}$ Edwards, Civil Society, 20.

Khazanah, Vol. 17 (1), 2019 
interesting of those debates is how they understand the kind of democracy influence on how they make civic culture matters on it. Almond and Verba see democracy as participation. Moreover, Glover uses the word "political efficacy" to express that an individual could influence collective actions if he/she wishes to do so. ${ }^{25}$ While, Garcia uses the term "liberal privatism", in the context of Spain which only has a democratic system, to describe the condition of the people who do not have a participatory activity. ${ }^{26}$

Scholars who are in the position to declare that civic culture is a matter for democracy have the same view. For them, a healthy democracy is the active participation of society to jointly assist the government. Within the context of a plural society, such as in Banjarmasin, it is necessary for democracy to embrace pluralism. All citizens regardless of their religion, ethnicity, and cultural background can live together as well as have the same right to actively participate in assisting the government. Hence, in order to achieve that, civil society must become a place to foster a civic culture that supports those conditions, such as tolerance and equality.

\section{The BPK Characteristic as Civil Society in Banjarmasin}

It is difficult for a member of BPK to find financial personal benefit if they utilize it as their daily income. Taufiqqurrahman, a BPK member, explains that sincerity is required to help each other. Otherwise, most of them spend their own money on BPK basic need such as

${ }^{25}$ Troy D Glover, Kimberly J Shinew, and Diana C Parry, "Association, Sociability, and Civic Culture: The Democratic Effect of Community Gardening," Leisure Sciences 27, no. 1 (January 1, 2005): 77, https://doi.org/10.1080/01490400590886060.

${ }^{26}$ Rafael Vázquez García, Civil Societies and Social Movements: Potentials and Problems (London: Routledge, 2007), 29. 
petroleum for vehicle unit and pump equipment, also maintenance. Moreover, if there is a big fire, they always have the initiative to collect fund contribution for victims. Thus, for Taufiqqurrahman, they cannot expect a personal financial benefit in BPK. So it requires a high level of social awareness and voluntary to help each other in becoming the real BPK members.

Reflecting on that issue, BPK also has a characteristic of voluntary. Ahnaf stated that civil society is an organization outside a business. ${ }^{27} \mathrm{BPK}$ is a voluntary association which is not oriented on business and economics.Their main objective is to help the society. Their prime income mostly comes from the funding from collective or individual.

The second aspect is public awareness. Ahnaf and Edward both highlighted that civil society is a social association that attentive towards the social matter. The main objective of BPK in Banjarmasin is the public interest. Most of the duty and activities of BPK are closely related to society and social, such as helping in extinguishing the fire, fire disaster to evacuation, flood victims, mitigating a disaster, traffics management, and even preventing ethnic conflict between Dayak and Madura in Banjarmasin in $2016 .^{28}$

According to Larry Diamond, the characteristic of civil society is to "make demands to the state." Based on the case study of BPK in Banjarmasin, civil society helps the state to fulfill the state's demand. The main task of BPK is to extinguish fire disaster, which in this case it should be the government's task. Furthermore, helping accident victims and

${ }^{27}$ Ahnaf and Widyantoro, "Democracy, Uncivil Society and Development: Evidence from Indonesian Province of Yogyakarta," 4.

${ }^{28} Y e s i$ Yonefendi, Pawito Pawito, and Mahendra Wijaya, "Cultural Identity PostConflict: Crisis of Madurese Culture Identity in Sampit Central Borneo after Ethnic Conflict," International Journal of Multicultural and Multireligious Understanding 5, no. 5 (October 25, 2018): 307, https://doi.org/10.18415/ijmmu.v5i5.444.

Khazanah, Vol. 17 (1), 2019 
evacuation are the tasks of police, and finding drowning victims is the task of the national rescue team. Should be noted, rather than taking over the government's duty, BPK in Banjarmasin assists the government. Hence, within these circumstances, BPK in Banjarmasin has both characteristics, which are "cooperative" or "public awareness", as a form of civil society.

The behavior of tolerance is shaped by the dynamic culture related to pluralism practices within civil society. This also happens in BPK communities in Banjarmasin. Though BPK Banjarmasin is a form of civil society, their members also become part of other civil society in the larger area. Thus, their tolerance behavior also has a range and diversity. Moreover, the civic culture that shaped by daily basis practices in BPK contributes to the level of acceptance toward differences both as a group and as an individual.

\section{Pluralism Practices in BPK Communities as a Group}

Robert Putnam referred civic engagement to all activities that build social capital. For Putnam, civic engagement may include informal social activities (visiting friend, playing card, etc.) up to formal activities (community service, political participation, etc.). ${ }^{29}$ Using Putnam's description, I categorize the form of pluralism practices in BPK Banjarmasin into two: the informal and formal activities.

In the informal level, pluralism practices take form as informal gathering (waktu takumpulan) in command post (posko) and the active communication through Handy Talkie (HT). For the member of firefighter community, posko is not merely command center where all

${ }^{29}$ Robert D. Putnam, "Bowling Alone: America's Declining Social Capital," in Culture and Politics: A Reader, ed. Lane Crothers and Charles Lockhart (New York: St. Martin Press, 2000), 185, https://doi.org/10.1007/978-1-349-62397-6_12. 
the information gathered and spread over. Posko also becomes their "second house", the place where most of their activities happen. "Posko is not only a place to keep firefighter equipment and vehicles, but also a center of gathering for the members and society," said Ahmad Mujib, one of BPK Banua Anyar member. When there is no accident or fire occurrence, the members of BPK usually come to posko just for socialize with other members or stand by while waiting for the alarm. In fact, though on daily basis the activity in posko is started around 9 P.M., most of the posko are never empty, especially during the night, holiday, or after the fire incident. They call their gathering time as waktu takumpulan.

During the gathering, they chat and talk about many things, from trivial matters such as their work condition, the price of cigarettes, up to developing issues in the society, and sharing experiences when they are on duty. Each member is called out by their nickname as the form of closeness. They also spend their spare time on the posko by playing card or chess. "Basically, whoever is allowed to come to the post even though he is not the member of BPK," said Yanti, member of BPK Banua Anyar. Before joining in BPK, Yanti often goes to the posko to meet with others and socialize. This closeness gathering attracts her to join in $\mathrm{BPK}$ as a member. After joining the BPK, she regularly goes to the post to reduce stress because there is always "behapakan" or jokes within their chat.

Other than waktu takumpulan in posko, the pluralism practices in BPK can also be identified through their active and intense used of handy talkie as a medium of communication as well as civic engagement. Handheld Transreceiver also was known as a walkie-talkie or Handy Talkie (HT) for Indonesian is widely used among amateur radio operators and disaster mitigation due to their capability to broadcast 
voice informative without depending on the third party. BPK in Banjarmasin used the HT as the prime communication device to have coordination during the accident as well as to socialize with each other. Should be noted, most of the firefighter community members have their own occupations and works during the day while the accident can happen anytime. Thus, in order to overcome this limitation, they use HT as a medium of communication and share the information. As remarked by Jerry 911, a member of BPK Hippindo in the previous chapter, the role of HT for active BPK member is like a cellular phone (HP) for common people. During emergency or standby situation, every BPK always brings HT whenever they go. Yet, if the situation is calm and there is no emergency, they use HT as a medium to greet each other, joking and also discussing the public issues. From HT also, the member of BPK from different organizations knows each other and engages in broader relation outside their community. In order to manage the dual functions, as the center of emergency information and socialization, they open several lines, for example, Emergency 500, Balakar 654, and KGE which are usually affiliated with their big group of BPK, that have different purposes. Moreover, there is also channel managed by the government called "Banjarmasin Siaga." This channel only broadcast information about the emergency situation or discussing serious matters related to potential conflict or accident. In the case of emergency, all channels are immediately switched and become an emergency channel. There is no joking or discussion about trivial matters until the situation is being handled well.

On the formal level, pluralism practices take place during the accident or fire occurrence. When there are fire occurrence or emergency situations, BPK comes to the site where accidents happen. There, they meet with other people and help regardless their background. Facing life- 
death situation, the BPK member learns to put their humanity first before their private or group interests as well as learn about the others.

These circumstances are in line with what Fukuyama argued as "school of citizenship." Fukuyama stated that civil society is, "school of citizenship which has the goal of creating individuals who have habits of cooperation and concern for public issues." 30 Hence, the gathering in posko, intensely used of HT, as well as their activities during the accident put them in the situations that always concern the problem of their communities. Moreover, the intense discussion through HT or in waktu takumpulan about their city developments, firefighter, and life-saving matters foster their public awareness. In addition, by meeting with other people from various backgrounds in BPK especially, the member of $\mathrm{BPK}$ begin to learn and accept the differences as well ignite the civic culture of tolerance for them.

\section{Pluralism Practices in BPK Communities as an Individual}

Members referred the narratives are the primary picture of analysis. Three of them (BPK Perintis, BPK Masjid Noor, BPK Banua Anyar) represent a member of BPK community which hashomogenous members and the rest (BPK Seberang Masjid, BPK Kompas, BPK ST 15) represents a member of BPK which have heterogeneous members. All the respondents have qualified the standard of young adult to middle-aged $22-58$ year-old and active member of BPK who has joined BPK at least for 3 years.

The first one is Apriyanti (22), a female member of BPK Banuanyar. Yanti, as she usually called, is a Muslim and Banjarese. At first, Yanti and her mother have a food stall that often becomes

${ }^{30} \mathrm{Mr}$ Francis Fukuyama, Social Capital and Civil Society (International Monetary Fund, 2000), 7.

Khazanah, Vol. 17 (1), 2019 
gathering place by BPK member. Attracted to their activity, Yanti decided to join BPK member. "I think it will be very difficult for a woman to join BPK, because in my mind initially, BPK is a man's job, but they do not see whether you are female or male, all the same in their eyes," said Yanti. Basically, most of the members in BPK Banua Anyar are connected by family ties and it's hardly seen a member from outside. Thus, when joined BPK Banua Anyar at the first time, she didn't know much people. "But what keeps me from being a member of Banua Anyar is the way they joke. They like to joke and mock each other but no one feels offended. It makes me feel so familiar with them," said Yanti who just finished her high school and just recently took a course to become airport staff. Yanti lives in the homogenous society who has stiff Islamic cultures. By joining BPK, she encountered with other people outside her community and become more open to communicating with other people who have a different background. "In the field, I often meet, interact and cooperate with other BPK members. That is where I started getting many friends give experience for me to recognize people with different backgrounds from various BPK in Banjarmasin," Yanti remarked.

The second is H. Hendra Setiawan (34), field coordinator in BPK Perintis. H. Hendra is a Banjarese Muslim who has been performed hajj pilgrimage. H. Hendra joined BPK Perintis since he was 19 years old. At that time, though lives far away from the main office of BPK Perintis, Hendra has a close relation with H. Faisal, the leader of BPK Perintis that become one of the reasons he joined firefighter community. BPK Perintis send H. Hendra to be trained on firefighter skills in Jakarta and ever becomes the runner-up of firefighter skills competition in Java. After actively joined as well as become one of the coordinators in BPK, Hendra encounter with various people outside his community. 
Furthermore, as field coordinator in BPK Perintis, Hendra has a close relationship with the church. When the church around BPK Perintis' jurisdiction celebrates some religious events, they contact Hendra to help them manage the parking lot and traffic without paying any cost or retribution. These encounters help him to accept the differences as well as build his connection with others community. "For me, interacting with other people with different religious backgrounds is very common, because my parents have different beliefs. But in BPK I learn a lot about understanding each other and not too picky when helping the others," said Hendra. In BPK, during the accident, what matter most is to extinguish fire whether it is a house of the officials or ordinary people, Christian homes, Dayak houses, or anyone.

The following respondent is Juhran Amrin (27), member of BPK Masjid Noor. Juhran is Muslim and Madurese. Since junior high school, Juhran becomes the member of BPK Batur that located near his house. However, 3 years ago, Juhran joined BPK Masjid Noor in order to gain more experience and prestige. Juhran comes from religious families that have rigor perspectives about Islam and the Habib-ness. After joined BPK, Juhran is becoming more open toward other religion by having more interaction with them. As a member of BPK Masjid Noor, Juhran actively involved in social activities such as together with cancer volunteer of Banjarmasin finding a blood donor for young people with cancer, assisting the leaders or anyone to activate and manage their social and health insurance (BPJS), especially for those who do not understand the procedures. Yet, outside the emergency situation or the same BPK members, Juhran do not many encounters with another religious adherent. "Indeed, there is no non-Muslim member in BPK Masjid Noor. Maybe they feel uncomfortable to join because this is obviously a BPK affiliated with the mosque. Besides, the figure of Habib Khazanah, Vol. 17 (1), 2019 
in BPK Masjid Noor is strong," Juhran remarked. In fact, by joining BPK that led by Habib, his perspectives toward Habib-ness becomes stronger. "Habib is never wrong since he is the descendant of prophet Muhammad. Basically, we as a good Muslim should be 'sami'na wa atho'na' or do according to whatever is presented by the teacher," said Juhran. For him, and other BPK member of Masjid Noor, Habib Salim is not the only leader in BPK, but also as a mentor in religious matters. In fact, as told by Juhran, Habis Salim ever gave advice that while becoming a BPK member the most important thing we need to know is to help people, have a true worship, and obey what the teacher said because the teacher never wants to plunge his students.

The fourth respondent is Rudi Febianto (35), member of BPK ST 15. Rudi is a Javanese and a Christian. Rudi Febianto is ex-ST 17 member who also established BPK ST 15. Located in the area with the multicultural resident, Rudi often meet with people from diverse backgrounds during his enrollment as BPK. Moreover, the BPK where he affiliated with has heterogeneous members. By joining BPK, he learns that what's important is what you can do and not where do you come from. In order to overcome the emergency situation, what we need is the ability and not identity. "We have the same principle, not only in BPK but in anywhere. Even though you are Chinese and Christian, you could become the leader of BPK as long as you have the quality," explained Rudi. Though most of the members in BPK ST15 are Muslim and Madurese, the leader is a Chinese descendant name Rudi Atmaja. Furthermore, the strong hierarchy that becomes characteristic in BPK does not prevent the members to interact with others regardless their positions or seniority. "I am with Rudi Atmaja who is a Chinese, Confucian, and a rich man is like a brother. I am with Pak Fredi Manurung, a Batak and Christian also like brother, and so does the other. 
I called Mas Rudi Atmaja by Koh Go Kong. Because I used to watch Chinese movies Sun Go Kong, just like Mas Atmaja, hahaha," Rudi added. By having more time to spend together, Rudi and other BPK member indirectly create this togetherness. They often share stories about family, the situation at work, experiences. "We never looked at your status. If you have good intention in BPK, you could be my brother. But if you try to find money here, you won't stay long," Rudi concluded.

The subsequent respondent is $\mathrm{H}$. Goler (58), chief leader of BPK Seberang Masjid. H. Goler is Banjarese Muslim. H. Goler established BPK Seberang Masjid in 1987 in Kampung Melayu due to big fire accident there. During 30 years experiences of becoming BPK member, H. Goler already encounters and works together with the people from various background. Moreover, during his leadership, BPK Seberang Masjid becomes one the biggest and wealthiest BPK. "It is because we accept all the people regardless their background as long as they have a sincere will to help others. Besides everyone is equal in God's eyes," H. Goler explained. He shares this principle with other BPK members. During 2016 crisis, this principle helps him and other BPK members to overcome the escalating conflict during 2016 crisis. They do not see other as part of particular tribe or ethnicity, but rather as the same community. "Our members come from Dayak and Madura also. They are all our brothers. If they make a riot and then get hurt, can we just close our eyes and said, 'that's none of my business'? Just consider it like fire. Consider all fires accident that happens is at in our family home. We will die trying to extinguish it, didn't we? So there is no thought, 'oh he is Christian, oh he is Chinese, oh she is Madurese or Hindhu. There is only, oh he is my brother. I need to help him," H. Goler remarked. In other 
words, for H. Goler, becoming BPK member is all about brotherhood and helping each other voluntarily.

The last is H. Shomad (55), chief leader of BPK Kompas, Banjarese Muslim. He is the leader as well as the founder of BPK Kompas after the ethnic clash between Banjarese and Chinese in 1997. Located in the area that becomes the red zone for fire accident during 1997 chaos, H. Shomad has initiatives to establish BPK. Should be noted, H. Shomad is a Muslim who lives around Chinese descendant residency. Actively involved as BPK community in the area that prone to conflict and fire accident, H. Shomad learns that by living together with the people who apparently have many differences with us, we found that we are basically the same. This awareness is strengthened when he actively involved in BPK community. He saw that every BPK member regardless their background and ethnicity are doing the similar thing like playing chess or gaplek, drink coffee, joking around, and so forth. "In social life, especially when the accident happens, we are basically the same. Just because you are Chinese, you cannot be dirty and do not take the hose or just because you come from Java you don't afraid of the heat. No. We're the same and you will experience that when you become BPK member," said H. Shomad.

According to the evaluation, there are different results in acceptance of others between respondent in BPK which have homogenous members and heterogeneous members. In BPK which have homogenous members, the tolerance toward other mostly limited among BPK members and they have less interaction with other people who have a different background. Juhran is one example. The homogeneity of the member in his BPK makes them seldom encounter with other people from different religion or ethnicity. Thus, his perspectives toward others who have a different belief with him still 
negative and thus he limited his daily encounter only with the community that he already knew. Similar things also happen with Yanti.

On the contrary, respondents who join BPK which have heterogeneous members have more tolerance toward others. Both $\mathrm{H}$. Shomad and H. Goler have great acceptance toward others. For them, in social and emergency matters, people basically are the same. For years in BPK, they work with people from various backgrounds and lived around them. The daily encounter with BPK members, as well as part of society on a daily basis, shapes their awareness about plural society and tolerance among others. The frequent encounters also shape Rudi's mindset in BPK ST 15. His experiences in BPK teach them about equality. "Even though you are Chinese and Christian, you could become the leader of BPK as long as you have the quality," explained Rudy. What important is what can you do to the society regardless your backgrounds. "Within the context of civil society, Uslaner and Brown identified that "inequality may depress participation, either directly or indirectly, through its effects on trust. ${ }^{31}$ " Here the sense of equality becomes an important factor to sustain the civil society.

Meanwhile, within the context of social network typology, Putnam differentiated the social networks into two: bonding and bridging. Essentially, bonding is defined as bringing "together people who are like one another in important respects (ethnicity, age, gender, social class, and so on)", while bridging is, "bring together people who are unlike one another. ${ }^{32}$ The BPK which have homogenous membership tend to have bonding social network rather. On the other hand, BPK with more

31 Eric M. Uslaner and Mitchell Brown, "Inequality, Trust, and Civic Engagement," American Politics Research 33, no. 6 (November 1, 2005): 859, https://doi.org/10.1177/1532673X04271903.

${ }^{32}$ Robert D. Putnam, Bowling Alone: The Collapse and Revival of American Community (New York: Simon and Schuster Paperbacks, 2001), 11.

Khazanah, Vol. 17 (1), 2019 
heterogeneous membership has more internal bridging social network that helps them to make external bridging with other communities.

Thus, the encounter with other people who have a diverse background is important. Through their frequent encounter, they learn more similarities with the people who appear different from them. Many scholars already highlighted that associations with a more heterogeneous membership give them, in themselves, more opportunity for crosscutting ties across socio-economic cleavage lines. In the case BPK Perintis, though the BPK has a strong characteristic of bonding social network, H. Hendra Setiawan has a more public awareness of tolerance. His position as field coordinator gives them more opportunity to actively encounter and work together with people who have different backgrounds.

Interesting to note, there are common values that upheld by the respondents from a heterogeneous and homogenous group: the brotherhood of BPK and help others regardless their background during the emergency. Through active civic engagements, there are senses of kinship among BPK member regardless their affiliations and their backgrounds. The concept of sanak ikam (our own brother) frequently becomes a cure when there is conflict among BPK members. Furthermore, as the case of Juhran, the acceptance among BPK member is higher than the general acceptance of society outside BPK. Varshney argued that "Everyday engagement between ethnic groups may be better than no interaction at all." ${ }^{33}$ In addition, everyday interethnic engagement is relatively enough to maintain peace on a small scale. This is what happens in BPK Banjarmasin on daily basis. Their daily interaction

${ }^{33}$ Ashutosh Varshney, "Ethnic Conflict and Civil Society: India and Beyond," World Politics 53, no. 3 (April, 2001): 392, https://doi.org/10.1353/wp.2001.0012. 
through waktu takumpulan in posko and HT help them to know each other and build a civic culture of tolerance.

\section{Politic and Contestation among BPK}

The large number of BPK in Banjarmasin also has prone to conflict. In fact, the conflicts between BPK frequently happen especially during extinguishing fire. Usually, the problem is also finished when the fire successfully extinguished. Yet, if the problem continues, the chief of each BPK will meet and mediated by the elder BPK. The priority in discussing this kind of problem is whether any members are injured, whether they have been treated or not.While friction itself usually resolved by reminding each other that they are actually brothers, as fellow BPK. The brotherhood of BPK becomes a civic culture that upheld by the members of BPK regardless of their background and organizations.

However, this brotherhood also might become a threat toward pluralism and civil society itself. If we take a look at the history of BPK establishment, BPK becomes a vessel to distinguish or demarcate between local and Chinese descendant in Banjarmasin. This happens due to stronger bonding practices rather than bridgingpractices.

Within the case of BPK in Banjarmasin, the civic engagement to gain social capital is begun with individual initiatives for voluntary participation in the public sphere. This initiative becomes a pattern for many rich people in Banjarmasin. Whoever wants to participate and be known in the public sphere, they choose to initiate a BPK or give funding to establish BPK. However, it does not rule out the possibility that this individual voluntarism and organizational involvement might change into 
electoral participation machine. As shown by Ahnaf, political opportunity often becomes a significant factor of horizontal conflict in a society. ${ }^{34}$

This also affects the competition among BPK, because many BPK founders are rich people, so they want their BPK to be the best BPK, both in terms of vehicles, machinery, and equipment also achievements. So that BPK not only becomes a good prestige competition for BPK founders but also its members, to be a better BPK than others, so it is possible that it also happens when in a fire accident, they race to come the fastest to the location off iredisaster, get the best position in extinguishing the fire and have a big contribution in extinguishing the fire in that area, to gain prestigious and recognition from other BPK.

The strong brotherhood that BPK had, not only having a positive side as an igniter tolerant to all members of BPK but also have a negative side in it which is potentially damaging to the tolerance itself existing in society because it has an indication as bridging in bounding civil society. Furthermore, it also has a possibility of ending up in conflict because BPK has only Bridging in their internal, only tolerant of people with different backgrounds as long as they have the same identity that is BPK members, which then make them an inclusive association in terms of internal but exclusive in an external context.

\section{Conclusion}

Independent firefighters community (BPK) in Banjarmasin with their characters that are, voluntary whose membership is not based on business or economic base, then public awareness is BPK focusing on issues that occur in Banjarmasin society, moreover disaster and bridging with no exceptions against the background and identity of members such

34 Ahnaf and Widyantoro, "Democracy, Uncivil Society and Development: Evidence from Indonesian Province of Yogyakarta," 15. 
as religion, ethnic, social status and others. Provide a positive impact on the attitude of tolerance of its members. Seen from the way they help others in emergency situations who never choose who to help and who does not.

In addition, BPK Banjarmasin as a whole who has members with a high level of diversity is forming a brotherhood among its members. The attitude of "sanak ikam" or "your brother" brings up the attitude of civic members' tolerance of all the differences that exist in other individuals in general and differences in members of BPK in particular.

On a more personal level, a member's attitude towards tolerance can also be affected by the diversity of members in BPK their affiliated. It can be seen how members of the BPK who are more heterogeneous, have a more open mind and appreciate the difference and accept it, in the other hand, members who come from more homogeny BPK groups, they can still appreciate the difference but not to accept.

However, BPK that has grown very rapidly since 1997 has the possibility of being a place for political contestation. Especially for owners of BPK who coming from wealthy family, BPK becomes one of their ways to gain social capital and recognition from society. This raises competition among BPK to be better than others, so BPK could be transformed into a "pride competition".

This can be a barrier to BPK in fostering tolerance. This is because the political contestation of the owners and the "pride competition" between these BPK can lead to internal conflicts. Other than that, a very strong brotherhood of BPK can be a boomerang in fostering tolerance in Banjarmasin society. This is because there is no experience for BPK in facing conflict situation between BPK and the group outside BPK. It does not rule out of possibility BPK as bridging association but on the other side also bounding association. Thus, on one side BPK has been playing a role in fostering tolerance in Banjarmasin society, did not rule 
Muhammad Sandi Rosyadi

out the possibility in the future become a double-edged knife that even destroys the tolerance that has been formed.

\section{References}

Abidin, M Zainal. "Civil Society dalam Wajah Keislaman dan Keindonesiaan." Khazanah: Jurnal Studi Islam Dan Humaniora 12, no.2(August8,2014). https://doi.org/10.18592/khazanah.v12i2.1607.

Ahnaf, Mohammad Iqbal, and Hary Widyantoro. "Democracy, Uncivil Society and Development: Evidence from Indonesian Province of Yogyakarta." Development Research Conference in Stockholm University Panel on Democracy and Development, 2016.

Banjarmasin, BPS Kota. Kota Banjarmasin dalam Angka 2016. Banjarmasin: Badan Pusat Statistik Kota Banjarmasin, 2016.

Berman, Sheri. "Civil Society and The Collapse of The Weimar Republic." World Politics 49, no. 3 (1997): 401-429. https://doi.org/10.1353/wp.1997.0008.

Carothers, Thomas, and William Barndt. "Civil Society." Foreign Policy 10, no. 3 (October, 1999): 18-29. DOI: 10.2307/1149558.

Carson, Donald A. The Intolerance of Tolerance. Michigan, USA: Wm. B. Eerdmans Publishing Co., 2012.

Chandhoke, Neera. "Civil Society." Development in Practice 17, no.4 (November,2018):607-614.

https://doi.org/10.1080/09614520701469658.

Diamond, Larry. "Civil Society and The Development of Democracy." Estudios/Working Papers (Centro de Estudios Avanzados En Ciencias Sociales), no. 101 (1997): 1.

Doorn, Marjoka van. "The Nature of Tolerance and The Social Circumstances in Which It Emerges." Current Sociology 62, no. 6 (October,2014):905-927. https://doi.org/10.1177/0011392114537281.

Edwards, Michael. Civil Society. Malden,USA: Polity Press, 2009. 
Fukuyama, Mr Francis. Social Capital and Civil Society. International Monetary Fund, 2000.

García, Rafael Vázquez. Civil Societies and Social Movements: Potentials and Problems. London: Routledge, 2007.

Glover, Troy D, Kimberly J Shinew, and Diana C Parry. “Association, Sociability, and Civic Culture: The Democratic Effect of Community Gardening." Leisure Sciences 27, no. 1 (January 1, 2005): 75-92. https://doi.org/10.1080/01490400590886060.

Gutorov, V. A. "Civil Society and the Theory of Democracy: a View from Intellectual Heritage of the XX-th Century." RUDN Journal of Political Science 5, no. 1 (December 15, 2015): 50-60.

Lipschuts, Ronnie D. "Reconstructic World Politics: The Emergence of Global Civil Society." Millenium: Journal of International Studies 21, no.3 (December1,1992):389-420. https://doi.org/10.1177\%2F03058298920210031001.

Migdal, Joel S. State and Society: Studying How States and Societies Transform and Constitute One Another. Cambridge, UK: Cambridge University Press, 2003.

Putnam, Robert D. "Bowling Alone: America's Declining Social Capital." In Culture and Politics: A Reader, edited by Lane Crothers and Charles Lockhart, 223-234. New York: St. Martin Press, 2000. https://doi.org/10.1007/978-1-349-62397-6_12.

. Bowling Alone: The Collapse and Revival of American Community. New York: Simon and Schuster Paperbacks, 2001.

Putnam, Robert D., Robert Leonardi, and Raffaella Y. Nanetti. Making Democracy Work: Civic Traditions in Modern Italy. New Jersey: Princeton University Press, 1994.

Sugianto, Achmad. "Efektifitas Peran Serta Masyarakat Dalam Pengelolaan Pemadam Kebakaran (BPK) Mandiri Sebagai Fungsi Pelayanan Publik (Objek Studi: Kota Banjarmasin).” Masters, Program Pasca Sarjana Universitas Diponegoro, 2001. http://eprints.undip.ac.id/11895/. 
Muhammad Sandi Rosyadi

Uslaner, Eric M., and Mitchell Brown. "Inequality, Trust, and Civic Engagement." American Politics Research 33, no. 6 (November 1, 2005): 868-894. https://doi.org/10.1177/1532673X04271903.

Varshney, Ashutosh. "Ethnic Conflict and Civil Society: India and Beyond." World Politics 53, no. 3 (April, 2001): 362-98. https://doi.org/10.1353/wp.2001.0012.

Vogt, W. Paul. Tolerance and Education: Learning to Live with Diversity and Difference. Thousand Oaks, CA, US: Sage Publications, Inc, 1997.

Yonefendi, Yesi, Pawito Pawito, and Mahendra Wijaya. "Cultural Identity Post-Conflict: Crisis of Madurese Culture Identity in Sampit Central Borneo after Ethnic Conflict." International Journal of Multicultural and Multireligious Understanding 5, no.5 (October 25, 2018): 303-11. https://doi.org/10.18415/ijmmu.v5i5.444. 